\title{
Historical Science in the Countries of the European Union as a Factor of Unification and Reconciliation: Experience for Ukraine in the Context of European Integration
}

\author{
Dmytro Nefyodov \\ Doctor of Historical Sciences \\ Associate Professor at the Department of History \\ V. O. Sukhomlynskyi National University of Mykolaiv \\ nefyodovdv@gmail.com
}

\begin{abstract}
The article deals with the role and significance of the modern European historical science in the process of implementing the policy of reconciliation of nations. Based on the analysis of European countries experience several proposals have been made to establish a dialogue to consolidate the Ukrainian society. For today's Ukraine it is especially important to pursue such a historical policy that will promote the national historical reconciliation. The problem of vital importance is to develop a common conceptual approach to comprehension of the role of the historical policy and reconciliation policies for the security sphere of the state.
\end{abstract}

Key words: European Union, integration, the historical science, education, reconciliation

The historical education in today's Ukraine is undergoing a period of transformation towards the tolerance to cultural differences. These transformations reflect the changes that took place in the late 1990s, when many European countries were in a state of transition as a result of global democratic changes, when actual reinterpretation of numerous concepts began, including the historical fate of Europe.

Presently in Ukraine the requirement to construct the national historical narrative as an important ingredient of formation of the modern Ukrainian nation has been enshrined at the constitutional level. Thus, Article 11 of the Constitution of Ukraine affirms that "the state promotes consolidation and development of the Ukrainian nation, its historical consciousness, traditions and culture" [1]. Constructing one's own history is regarded as a fundamental need of the society in the context of own self-identification [2].

In 1993 at the meeting in Vienna the leaders of the EU member states highlighted the necessity of a radical reform of the content and objectives of school historical education so that it could correspond to the course of close integration in Europe [3]. That year the EU Parliamentary Assembly adopted "Recommendations for Learning History in Europe". At 
the pan-European level the Council of Europe executed the following projects: "Learning and teaching the history of the $20^{\text {th }}$ century in Europe" (1998); "European dimension in history teaching" (2002); "The image of the other" (2006). International seminars, conferences, consultations and expert evaluation of programs and standards in history are taken place regularly. Meetings of experts of Council of Europe with History teachers, methodologists, lecturers, authors of textbooks are organized. There are international organizations that study problems of the content of school historical education.

In the project investigation "Youth and history" more than $80 \%$ of teachers answered the question "What tasks of historical education do you pay the most attention to?" in the following way: "I'd like my students to acquire the main democratic values" [4]. It is essentially important as regards the youth survey which showed a strong connection between the historical consciousness of the younger generation and its assessments of the past, present, future outlook. That is why in the centre of historical education there should be a Man - strange and special, outstanding and average, but close to a student's perception. In this way only the task of formation of a responsible and active citizen by history, prevention of crimes against humanity can be realized.

The policy of reconciliation for the sake of common progress has become a cornerstone of EU countries' domestic and foreign policy. This reconciliation is a result of a difficult compromise, in which penance and mercy are mixed up with pragmatic realization of political expediency. In this reconciliation model the historical science has a dominant role.

Recognition of the core role of education and the issue of teaching history is one of the priorities for the Council of Europe, which applied for professional historians with a request to adhere to the three basic principles: history without propaganda, history without prejudices and history based only on real facts. The project "Learning and teaching history of Europe in the $20^{\text {th }}$ century", initiated by the Council of Europe, is based on the interdisciplinary and pan-European background. The immediate result of the project realization became the recommendation "On teaching history in the $21^{\text {st }}$ century in Europe". The document covers the issues such as purposes of teaching history, the European dimension, the content of the program, methods of teaching, teacher training, information and communication technologies and misuse of history. It notifies that deeper interpretation 
of contemporary European history can serve to prevent conflicts. The historical material should be presented through a dialogue and on the basis of multi-perspective. School must develop students' ability to think critically and resist manipulations and misuse of history. The material should neutralize prejudices and stereotypes, highlighting positive interaction between different countries, religions and scientific schools in the process of historical development of Europe in school programs [5]. In 2011 the Recommendation of the Committee of Ministers to member states "On intercultural dialogue and the image of the other in history teaching" was adopted. It specifies the directions of the reform of history teaching aimed at its contribution into intercultural development and emphasizes the dialogical coverage of history in post-conflict situations [6]. The European countries experience with regard to initiating broad-ranging public debates, discussions, surveys on problems of national identity, historical memory in society, seems positive.

In the European Union historical policy as part of reconciliation policy is considered to be a political technology aimed at developing important social, historical and political images as well as identification images, which is realized through public debates, education and mass media.

Over the past few decades the development of the national historical science was accompanied by conflicts of historical interpretations. In Ukraine there are significant regional differences in interpretation of historical events and processes. Purposeful manipulations by history, speculations on regional historical differences inspired regional political discrepancies. Consolidation of the Ukrainian society requires transferring of conflictive interpretation of events and processes into the field of public dialogue and solving them with the help of European democratic mechanisms. In European political culture it is a tradition of pluralism, that is acceptance of plurality of memories and interpretations as a norm. The European principle isn't aimed at intrusion of only one reading of history, but comprehension of conditions of co-existence of different experience.

Therefore, it's especially important for Ukraine to pursue the policy in the way that will facilitate national historical reconciliation. To consolidate the society it is necessary to promote the subjects that unite all the regions. The historical education takes a special place in the process of reconciliation, because school influences the young generation's consciousness to a great extent. Whereas school textbooks form national mythologies based 
on the historical narration, directly or indirectly create "the enemy image", for their levelling it makes sense to make common school textbooks by writing teams of different countries or to present different points of view in available national textbooks. The mechanism for holding round tables of national reconciliation, broad public discussions, conferences etc. is approved in the European tradition of getting over a conflict situation in the political life of the country, which has historical origins and harmful memory.

Under decentralization the implementation of historical policy generally allows a paradoxical combination of two mutually exclusive attitudes to formation of all-Ukrainian and regional historical memory, and hence stimulation of general civic and regional identity. The problem of vital importance is to develop a common conceptual approach to comprehension of the role of the historical policy and reconciliation policies for the security sphere of the state.

\section{References}

1. Konstytutsiia Ukrainy: Zakon Ukrainy vid 28.06.1996 № 254k/96-VR [Constitution of Ukraine]. URL: https://www.president.gov.ua/documents/constitution

2. Chuprii L. V. Istorychna osvita, yak skladova derzhavnoi polityky pamiati [Historical education as a component of the state policy of memory]. URL: http://sd.net.ua/2011/06/20/istorichna-osvita-politika-pamyaty.html.

3. Stradlinh R. Bahatorakursnist u vykladanni istorii [Versatility in teaching history]. Strasburh: Vydavnytstvo Rady Yevropy, 2004. 65 p. URL:

http://www.coe.int/t/dg4/education/historyteaching/Source/Notions/Multiperspectivity/Multi perspectivityUkrainian.pdf

4. Kriins Kh. Yevropeiski obrii istorychnoi osvity [European horizons of historical education]. URL: http://www.novadoba.org.ua/ukr/node/69

5. Rekomendatsiia Komitetu ministriv Rady Yevropy «Pro vykladannia istorii u XXI stolitti v Yevropi» [Recommendation of the Committee of Ministers of the Council of Europe "On teaching history in the $21^{\text {st }}$ century in Europe"]. URL:

http://zakon5.rada.gov.ua/laws/show/994_729

6. Rekomendatsiia Komitetu ministriv derzhavam-chlenam «Shchodo mizhkulturnoho dialohu i obrazu inshoho u vykladanni istorii» [Recommendation of the Committee of Ministers to member states "On intercultural dialogue and the image of the other in history teaching"]. URL:

http://www.coe.int/t/dg4/education/historyteaching/Source/Results/AdoptedTexts/CM\%20Re c(2011)6_Ukrainian.pdf 